\title{
Pontos cantados de pretos-velhos na Tenda Luz do Oriente: memória e ancestralidade
}

\author{
Candomblé chants of black-old in Tenda Luz \\ do Oriente: memory and african ancestry
}

Mayara Cristiny Souza Martins Rodrigues ${ }^{1}$

http://lattes.cnpq.br/4546814133794720

Ana Carolina Magno de Barros ${ }^{2}$

Enviado em: 21/08/2018

Aceito em: 07/12/2018

Resumo: Este artigo é fruto do fechamento do curso de especialização em Estudos linguísticos e Análise literária realizado na Universidade do Estado do Pará, o qual tem como objetivo interpretar os pontos cantados advindos do terreiro de Umbanda Tenda Luz do Oriente, utilizando para isso a metodologia da cartografia e os conceitos de ancestralidade africana de Oliveira (2006) e memória para Ferreira (2003) como caminho para essa compressão. Assim, a pesquisa mostra-se em uma metáfora, divida em elementos do corpo: pés, coração e cabeça os quais apresentarão o trabalho, pois emergiram ao longo da pesquisa, dando forma e desenvolvimento para o trabalho.

Palavras-chave: Umbanda. Pontos cantados. Memória. Ancestralidade.

\begin{abstract}
This paper is the result of the specialization course in Linguistics and Literary analysis attended at the University of 'The State of Pará, (Brazil). Its aim is to interpret the candomblé chants which come from the Umbanda ground East Light Tent, to this end, it was used the cartographic methodology and the concepts of African ancestry according to Oliveira (2006) and memory from Ferreira (2003) as a pathway for this interpretation. Thus, the paper displays itself as a metaphor, divided the body elements: feet, heart, and head are going to present the paper, since they ended up emerging along the research. They are like a ball of thread to be uncurled and, consequently, it gave the shape for the development of this paper.

Key-words: Umbanda. Umbada chants. Memory. Ancestry.
\end{abstract}

\section{A ida ao terreiro: conhecendo o espaço}

Mizifíos, é tempo de revelações e a única coisa que salva a gente da ciranda das reencarnações é o amor. Quando o amor é verdadeiro, a verdade logo aparece. Todo mundo fala de Preto velho, todo mundo fala que são ex-escravos encarnados que viveram no Brasil, todo mundo é entendedor de Preto Velho ${ }^{3}$, mas não sabem de nada, essa é a verdade. Nem todos encarnaram

\footnotetext{
${ }^{1}$ Mestranda do Programa de Pós-graduação em Estudos Literários pela Universidade Federal do Pará. Formada em letras língua portuguesa pela Universidade do Estado do Pará. Especialização em Estudos Linguísticos e Análise Literária pela UEPA e em História Cultura afro-brasileira e africana pela FIBRA. E-mail: may.rodrigues@,hotmail.com.

${ }^{2}$ Orientadora: Mestre em Artes pelo Instituto de Ciências da Arte (ICA) pela Universidade Federal do Pará (UFPA).

Doutoranda na Universidade Federal do Pará. E-mail: carolmagno13@gmail.com.

${ }^{3}$ Pretos-Velhos: guias de luz e cura.
} 
no Brasil e nem todos foram ex-escravos aqui. Aqueles que sabem só sabe porque é permitido ter a chave do mistério.

A única coisa que falo dos Pretos Velhos para suncês é que eles são o amor. Eles são a força e a raiz de Guiné, são a palha de Omolu e Obaluaê, suncês não sabem o que isso significa né? Suncês não tem ideia o que isso representa? (Vovó Maria Conga) 4

O interesse por essa temática envolvendo negritude começou com o Trabalho de Conclusão de Curso (TCC) realizado em 2013 na Universidade do Estado do Pará (UEPA), para a obtenção do diploma em Letras. Essa monografia teve como objetivo analisar os elementos afro-brasileiros no livro Batuque (1937) de Bruno de Menezes, nessa pesquisa tive a oportunidade de estudar teóricos como Zilá Bernd e Roger Bastide que discutem sobre a poética negra. Além de verificar também, os elementos amazônicos na obra mencionada, o que me motivou para pesquisar sobre outras obras literárias de expressão amazônica que exploram essa negritude.

Após isso, aprofundei-me sobre nesta temática, realizando a especialização em História e cultura afro-brasileira e africana na Faculdade Integrada Brasil Amazônia (FIBRA) assim, pude estudar sobre temas afins, realizando, ao final, o trabalho intitulado $A$ literatura de expressão amazônica como registro histórico da cultura afro-brasileira no Marajó, que faz uma análise crítica e histórica da cultura afro-brasileira me aprofundei nestas seguintes passagens do livro Três Casas e um rio (1958): a personagem Dona Amélia quando incorpora na noite de São Marçal, além dos momentos em que Alfredo, personagem principal da narrativa, sente vergonha por sua mãe ser negra e conhece pela primeira vez um parente da sua família materna, o tio Sebastião, revelando ao garoto parte de sua herança negra.

Neste percurso, percebi a importância da religião de matriz africana para os estudos sobre identidade, literatura e negritude os quais me debrucei em pesquisas anteriores. Assim, a vontade de conhecer um terreiro me fizeram buscar esse espaço, no sentido de compreender toda essa experiência que até então só tinha lido. Foi a partir dessa curiosidade e necessidade que traçaram o caminho para essa presente pesquisa. Assim, frequentei durante três meses o terreiro ${ }^{5}$ de Umbanda Tenda Luz do Oriente, localizado na cidade de Ananindeua no estado do Pará, no Conjunto da Cidade Nova III, na Rua do Fio, onde me deparei com as giras ${ }^{6}$.

Encontrei diversos interesses de estudo durante as minhas idas para a tenda, a cada gira que assistia conhecia mais e deixando me envolver, me permiti sentir a presença dos Pretos e Pretas-Velhas, momento que mais despertou para essa pesquisa, pois era o dia de Cura ${ }^{7}$. Nesse dia, a curimba ${ }^{8}$ silencia, ficam somente os curimbeiros ${ }^{9}$ e as palmas da mão acompanhando, a casa fica cheia, tanto os filhos de santo, quanto as pessoas da assistência ficam vestidos de branco, é posta uma mesa branca ao lado esquerdo, os colchões são estendidos

\footnotetext{
${ }^{4}$ Essa epígrafe faz parte da memória pessoal, pois não pude gravar, nem tirar fotografias da Tenda; então, todas as idas ao terreiro escrevia em um diário as minhas experiências, sensações e tudo que lembrava que os Guias falavam, essa fala do seu Tupinambá como todas as outras epígrafes desse trabalho fazem parte desse diário.

${ }^{5}$ Vale lembrar que, cada terreiro é único, com suas especificidades e ideias, não podemos comparar a Umbanda praticada na Tenda Luz do Oriente a outra, mesmo que seja umbandista.

6 Gira: momento que acontece o sagrado; é nessa ocasião que os guias descem nos umbandistas, os filhos e filhas da casa.

${ }^{7}$ nome dado para descarrego espiritual, cura física por meio da fé, alívio emocional, tratamentos de todos os tipos, físicos ou psicológicos realizados pelos Pretos-Velhos na Tenda Luz.

${ }^{8}$ Curimba: atabaques, instrumentos que são tocados durante as giras.

${ }_{9}^{9}$ Curimbeiros: filhos da casa que tocam os instrumentos, a curimba.
} 
no chão diante de cada banquinho, onde Vovós e Vovôs ${ }^{10}$ irão se sentar. E todas às quartas-feiras são assim, dia em que acontece esse trabalho, são cantados os pontos para que os guias ${ }^{11}$ possam fazer seus trabalhos, o que chamou atenção para a letra, pois são envolvidas de ancestralidade africana e de memória, surgindo dessa forma, a inquietação para pesquisa. A Umbanda feita na Tenda Luz do Oriente será como um fio condutor para a compreensão dos pontos cantados ${ }^{12}$.

Para essa compreensão da relação entre os pontos cantados, a memória e ancestralidade, debrucei-me sobre pesquisas que estão nesse diálogo. Assim, considerando o artigo Poética orais na Ilha de Colares-P A: proposta para uma cartografia da voz e da cultura das autoras Danieli dos Santos Pimentel e Josebel Akel Fares, para entender sobre uma metodologia de cartografia. Os estudos também de Eduardo Oliveira, Sandra Haydée Petit e Norval Batista Cruz, nas pesquisas: Epistemologia da Ancestralidade e Arkhé: corpo, simbologia e ancestralidade como canais de ensinamento na educação, respectivamente, foram fundamentais para a compreensão e aplicação do conceito de ancestralidade, além de perceber a importância do corpo para a cultura de matriz africana.

A dissertação de mestrado do programa de pós-graduação em antropologia da UFPA intitulada: O sacerdote e o aprendiz: etnografia, experiência ritual em um terreiro de Mina Nagô na Amazônia, de Hermes de Sousa Veras ajudou na estruturação do artigo, enquanto que os trabalhos Umbandização dos Cultos Populares na Amazônia: A Integração ao Brasil? de Yoshiaki Furuya e Um terreiro de Umbanda em Belém do Pará: terreiro do Rei Taculumi de Edson Soares Diniz possibilitaram o entendimento sobre a Umbanda na Amazônia, em especial, em Belém, e também, sobre a dinâmica, disposição dos espaços e a relação com a religião.

A partir das leituras mencionadas e das visitas à Tenda Luz do Oriente, o trabalho foi construído, assim, o corpo do texto está divido em três partes: "Pés descalços: retorno as terras das memórias", "Realinhando o compasso das batidas do coração com as melodias do batuque: os pontos de Pretos Velho" e, por último, "Oh Gira, deixa a Gira girar: sentindo os ciclos da vida". Divido, dessa forma, pois percebi a importância do corpo dentro da religião estudada, já que os pés, o coração e o movimento circular são sentidos na Umbanda, ou seja, as experiências e o próprio homem acabam sendo a Umbanda, então, as seções do trabalho também serão dividas a partir dessa lógica corporal.

A introdução será vista como os "descalçar os pés", pois ao entrarmos no congá13 precisamos tirar os sapatos, essa atitude nos faz retornar às raízes, em que a marca dos pés no chão nos faz sentir a Terra-Mãe, além do mais, simboliza para os umbandistas, não trazer a energia da rua para dentro desse território sagrado. Nesse sentido, nos propusemos a retirar todos os estereótipos e pré-conceitos para viver e sentir as emoções transbordarem nas giras tal como o trabalho, será também um desprendimento de fórmulas preexistentes e expor outras perspectivas para entender os pontos cantados dos Pretos-Velhos.

No segundo momento serão interpretados os pontos cantados, expus com a denominação: "Realinhando o compasso das batidas do coração com as melodias do batuque: os pontos de PretosVelhos", pelo fato de vivenciar o quanto o pulsar do coração bate no mesmo compasso das batidas da curimba (o atabaque). O som do batuque durante as giras revela, transforma,

\footnotetext{
10 Vovós/Vovôs: carinhosamente os Pretos e Pretas velhas são chamados assim pelos filhos da casa ou por aqueles que frequentam.

11 Guias espirituais.

12 Pontos cantados: são as músicas, acompanhadas pelo atabaque, palmas e vozes, os pontos cantados são entoados para que cada espírito venha participar da gira.

${ }^{13}$ Congá: altar, espaço onde acontecem as giras e as assistências.
}

https://periodicos.unifap.br/index.php/letras Macapá, v. 8, n. 3, $2^{\circ}$ sem., 2018 
emociona, envolve, nos proporciona o tombo ${ }^{14}$, capaz de nos deslocar daquele determinado espaço e tempo. De tal forma que, o trabalho também proporcionará essa experiência com os pontos, sentir e perceber o pulsar dos corações afro-descentes e o sangue negro os quais ainda emergem nas religiões de matriz africana, em especial, na Umbanda.

E por último, "Oh Gira, deixa a Gira girar: sentindo os ciclos da vida", é nítido a presença marcante do círculo, as giras, o congá e as danças têm essa disposição circular. E esse movimento acaba sendo a da nossa própria vida, em que vivemos ciclos, retornos e desfechos, essa dinâmica indica também não somente a conclusão da pesquisa, mais do que isso, ela indica que há momentos que precisamos retornar às situações nas nossas vidas para poder seguir adiante, e perceber que somos feitos de ciclos e que cada momento deve ser vivido e respeitado como tal.

Ao longo do trabalho serão feitas algumas discussões, primeiramente os estudos se baseiam na explicação do que é a religião Umbanda e sobre a prática da Umbanda na Tenda Luz do Oriente, em uma parte introdutória. Depois, serão discutidos os teóricos que falam sobre memória e ancestralidade, em especial, os conceitos de: arqueologia essencial, de Jerusa Ferreira (2003); e ancestralidade africana, de Oliveira (2006).

\section{Pés descalços como um retorno às terras das memórias: entendendo a Umbanda e a Tenda Luz do Oriente}

O Homem branco pensa muito, escuta mais os livros, escreve livros, tem muito papel e esquece da palavra, do coração. O homem branco precisa escutar mais, pensar menos, isso de livro não adianta muito, não resolve nada. (Seu Tupinambá)

O despir dos pés é, sobretudo, um retorno à minha própria história, às histórias contadas por minha avó e pela minha tia, quando narravam a incorporação da minha bisavó, ou coisas que viam, sentiam, sonhavam. As memórias desse tempo de criança em que o medo cedia lugar à curiosidade foram o impulso preciso para eu perceber que meu objeto de pesquisa, na verdade, já estava em mim, dentro da minha casa e família. Eu tinha sim, o pé no terreiro, mas precisava me reencontrar, e indo à Tenda Luz do Oriente proporcionou lembrar e entender as narrativas de terreiro em que eu sempre vivi.

A Umbanda é uma religião de matriz afro-brasileira, que surgiram nos estados de São Paulo e Rio de Janeiro em meados na década de 30 do século XX, em função da industrialização, políticas e urbanização dessas metrópoles. Ela é por isso considerada uma religião brasileira e, dessa forma, podemos identificar na Umbanda o sincretismo religioso do país, como o kardecismo, catolicismo, xamanismo e candomblé,

A formação da Umbanda como um sistema de crença e ritual se deu nas grandes cidades do Sul, como Rio e São Paulo, nas décadas de 1920-30, e há um consenso entre a maioria dos pesquisadores quanto ao papel da classe média nesse processo. Além do mais, diz-se que este foi um fenômeno profundamente ligado às evidentes transformações da estrutura social como a urbanização, industrialização e formação da sociedade de classes. (FURUYA, 1994, p. 18)

A sua definição é muito complexa e perpassa por vários meandros, desde a fundação até o seu conceito, essas diversas classificações não entram em consenso. Aliás, segundo

${ }^{14}$ Tombo: momento de transe espiritual. 
Emanuel Zespo: "religião-ciência" (ZESPO, 1946, p. 15 apud CUMINO, 2015, p.111), por não ser um puro dogmatismo e trazer para o culto um grau de organização a qual indaga e questiona. Já na Amazônia, temos o trabalho Umbandização dos cultos populares na Amazônia: a Integração ao Brasil? de Yoshiaki Furuya (1994), o qual expõe sobre o desenvolvimento, expansão, popularização e definições de terreiros quanto umbandistas na Amazônia brasileira.

Dessa forma, afirma que o primeiro passo para o fenômeno que denomina "umbandização da Amazônia" é a economia da borracha e a vinda para cá de nordestinos, em especial, de maranhenses, já que com eles houve a vinda também de elementos africanos que se agregaram aos que já haviam aqui.

O segundo momento da expansão ou da umbandização da Amazônia acontece mais tarde na década de 30, quando ocorre o Estado Novo de Getúlio Vargas, "a Umbanda aparece em cena nas grandes cidades do Sudeste" (Furuya, 1994, p. 28), há então um fluxo de informações, pessoas e trocas que acabam influenciando a religião umbanda na Amazônia. Assim, temos registro em 1938 de uma primeira casa em Belém:

Em Belém, [...], já em 1938 encontram-se alusões à Umbanda e os adeptos atuais estabelecem o início da introdução da Umbanda em Belém quando uma mãe-de-santo que praticava MinaNagô, combinou o Mina-Nagô com a Umbanda do sul após uma viagem ao Rio de Janeiro na segunda metade da década de 30. (FURUYA, 1994, p. 34)

Para a pesquisa, busquei a Tenda Luz do Oriente que segue a lei da Umbanda, e a primeira vez que fui para a gira, o guia ${ }^{15}$ Seu Tupinambá - chefe da casa ${ }^{16}$ - quem o recebe é a mãe Telma, a Matenta ${ }^{17}$, e seus ensinamentos ficaram remoendo inquietação e dúvida, e só mais tarde, revelaram-me, o presente trabalho: a memória e a ancestralidade, passado e presente se entrelaçando e se unindo na giras, foram essas palavras e sabedoria que foram decisivas para essa trajetória.

Esse terreiro está localizado na Rua do Fio, no bairro do Coqueiro, no Conjunto Cidade Nova III, em Ananindeua no estado do Pará, teve sua fundação em 19 de março de 2004, hoje, tem 14 anos. A tenda funciona às terças-feiras (na terceira de cada mês), quintas e sábados. Na quarta-feira ocorre o que denominamos de Cura:

A assistência é composta por pessoas que, regular ou esporadicamente, frequentam as giras. Podem ou não ser umbandistas. Algumas dessas pessoas costumam contribuir com doações para a manutenção do terreiro, festas, atividades assistenciais etc. [...] Para o bom andamento dos trabalhos, é muito importante as pessoas da assistência manterem o silêncio e o padrão de pensamento elevado, a despeito dos problemas pelos quais estejam passando. (BARBOSA, 2015, p.24-25)

Essa cura é feita pelos Pretos-Velhos e Pretas-Velhas, além disso, as atividades se estendem quintas-feiras com o dia do Xamanismo e os sábados com o seguinte ciclo: gira de Pretos-Velhos, gira de Juremas e gira de Encantaria (podendo mudar a ordem segundo os Guias, os filhos e filhas de santo só ficam sabendo na sexta qual será a gira), e em especial, a terceira terça-feira de todo mês acontece a gira dos Exus, Pombagiras ciganas.

Nesse contexto, vale observar que, cada gira as cores da curimba (os atabaques)

\footnotetext{
15 Guias: mestres espirituais.

${ }^{16}$ Chefe da casa: guia espiritual que direciona as ações durante as giras.

${ }^{17}$ Matenta: mãe da casa, no caso da Tenda Luz do Oriente, é a Mãe Telma.
} 
mudam, as cores dos panos de cabeça e do quadril, também variando de acordo com os guias que os filhos da casa recebem. A disposição da Tenda é feita da seguinte forma: há um grande centro, o congá, essa parte tem seu chão verde, onde acontecem as giras e as assistências ou curas, nas laterais (tanto esquerda quanto direita) estão encontradas as três filas de cadeiras onde as pessoas da assistência permanecem (que não são umbandista). Há, também, compartimentos atrás do altar central e um em cima, o primeiro onde ficam os materiais que são utilizados durantes as giras - instrumentos, cachimbos, roupas e materiais para as defumações, panos, bebidas, etc. - e o segundo é uma área restrita aos da casa, onde a Matenta (mãe da Tenda) e alguns médiuns moram nesse compartimento de cima. Enquanto o centro, no altar, e nas paredes das laterais estão os quadros pintados dos caboclos, índios, orixás e princesas, cocares, flechas, entre outros objetos sagrados.

Há dois altares nas laterais, antes do centro; uma do lado direito o outro do lado esquerdo. $\mathrm{O}$ altar do lado esquerdo (Casa de Exu), podemos encontrar as paredes pintadas de vermelho e branco, com dois quadros centrais, um é de a Cigana Dona Sarah, o outro é de Exu Tranca Rua da Aluguel, embaixo estão bebidas - vinhos e champanhes - velas, pentes, espelhos etc. E na entrada, há a imagem grande ao lado do Seu Zé Pelintra, de branco e vermelho, esse altar é das Ciganas, Exus, Pombagiras ciganas e malandros, os quais são evocados na terceira terça-feira de cada mês. Enquanto o altar do lado direito (Casa das Almas) são dos Pretos e Pretas Velhas, com retratos, imagens e algumas oferendas embaixo tal qual o primeiro, as paredes são pintadas de branco, lilás e o chão roxo. Logo abaixo, podemos ver a planta baixa da Tenda:

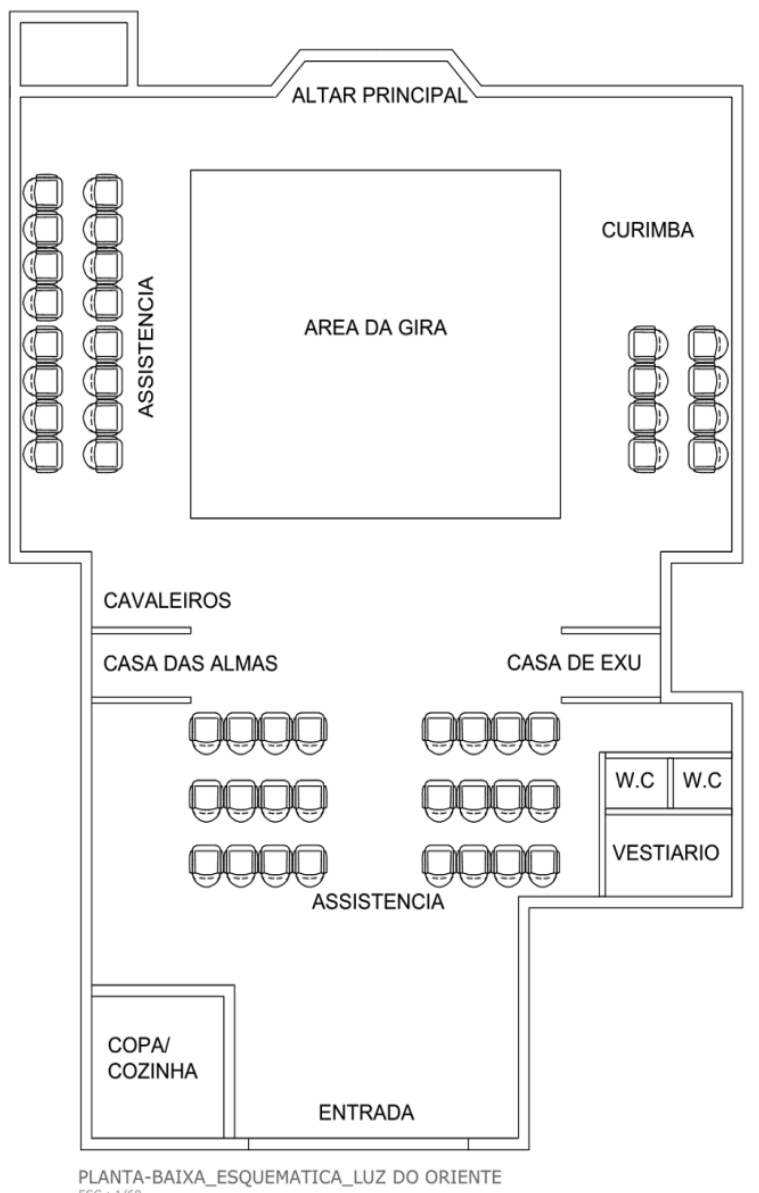

PLANTA-BAIXA_ESQUEMATICA_LUZ DO ORIENTE

https://periodicos.unifap.br/index.php/letras Macapá, v. 8, n. 3, $2^{\circ}$ sem., 2018 
As giras que me debrucei para o trabalho foram as de Pretos e Pretas Velhos, os chamados Vovôs e Vovós, podem ser assim descritas: a Tenda é arrumada, nessa gira não há curimba, apenas uma mesa branca, a qual a Matenta (Mãe Telma) comanda, em seguida, inicia-se com a defumação e segue a abertura da mesa, sendo cantados os pontos, a Vovó Maria Conga é a primeira a recebe é mãe da casa, enquanto os outros Vovôs e Vovós descem nos filhos e filhas de santo. As pessoas da assistência (externos à casa) são chamados individualmente e por nome, cada pessoa se deita em um colchonete de um determinado Preto-Velho.

\title{
Realinhando o compasso das batidas do coração com as melodias do batuque: os pontos cantados de Pretos Velhos
}

\author{
Que fumaça cheirosa vovô sai do seu cachimbo, \\ que fumaça cheirosa vovô sai do seu cachimbo. \\ Não sei se é arruda vovô ou se é manjericão. \\ Só sei que essa fumaça vovô, faz bem ao meu coração. \\ Só sei que essa fumaça vovô, faz bem ao meu coração. (Ponto de Preto-Velho)
}

A fumaça sobe, o coração bate apertado, enquanto o barulho dos cajados no chão começa a ficar cada vez mais frequente, o corpo encurva-se, a vela é acessa e o ponto no chão é riscado, o trabalho de cura inicia-se. Nas quartas-feiras percebi que todos os pontos cantados, os ensinamentos, o sagrado e as danças são apreendidas por meio da memória, assim, são levados aos filhos e filhas de santo as diversas funções, hierarquias, pontos, atitudes e rezas. O conhecimento vivido e compartilhado no terreiro é reconstruído a cada gira revivendo em cada ato a ancestralidade.

A interpretação dos pontos será feita mediante a metodologia da cartografia, com o método das anotações de cada gira que frequentei, conversas informais e vivências, sentindo os pontos cantados, pois como afirma Pimentel e Fares (2013), saindo da análise, explicação ou enquadramento de teorias para investigar os fatos, o pesquisador precisa além de estar inserido na comunidade, ter a sensibilidade de entendê-la e não impor nenhuma regra. Então, todas as interpretações feitas nesse artigo serão aquelas impressões e entendimento que obtive a partir das idas a Tenda:

\footnotetext{
Além disso, a busca do cartógrafo está ancorada na sensibilidade com que este segue cada etapa de seu itinerário, ao passar por acontecimentos tortuosos e das contradições dos espaços, de forma que o cartógrafo passa a compreender e ser afetado pela realidade das pessoas da comunidade. Aparentemente, o cartógrafo adentra no universo dos outros como um viajante estrangeiro que vai aos poucos descortinando outra realidade, desvendando e desvelando outros territórios antes desconhecidos. (PIMENTEL; FARES, 2013, p. 8)
}

Nesse sentido, no terreiro visitado os Vovôs e Vovós que descem são: Vovó Conga, Pai José, Pai Antônio, Vovô Dito, Vovó Benedita, Vovó Maria Redonda, Pai Joaquim, Vovó Catarina, Tia Maria da Bahia, Vovô Jeremias, Vovô Daniel, Vovô Cipriano, Pai Jacinto, Vovó Maria de Minas, Pai João D’Angola e Vovó Joaquina, Mãe Preta, Vovó Benta, Vovó Joana, Pai Barnabé, Pai Serafim, Pai Francisco, Pai Tomé, Pai Serapião e Pai Tomás cada um deles têm o seu ponto, e quando cantados, os guias descem nos filhos da casa. Não irei ler todos os pontos, são muitos e demandaria maior tempo, além de não ser o propósito da pesquisa, faço então, a leitura só de alguns pontos cantados. Inicio compreendendo o ponto da Vovó Maria Redonda, que foi um dos pontos que mais me emocionaram 
e foi o que acabou proporcionando o interesse para a presente pesquisa:

Fio se suncê precisar

É só pensar na vovó

Que ela vem ajudar

Pensa numa estrada longa zifio.

Lá no seu Jacuntá

E numa casinha branca, zifio

Que a vovó tá lá

Sentada num banquinho tosco zifio

Com sua rosário na mão

Pensa na vovó Maria Redonda fazendo oração

Disponível em: <http://pisanaumbanda .blogspot.com.br/2010/11/pontos-de-pretos-velhos_18.html.>. Acesso em: 10 de janeiro.

Nesse canto, destaco a afetividade e a relação familiar quando a Vovó se apresenta, usando sempre "filho" para falar conosco, além do mais, mostra que quando alguém estiver se sentindo mal, precisando de algo ou sofrendo, por exemplo, pediríamos a sua ajuda, diz que vai estar em um banco sentada esperando. É notório perceber, que quando lemos "filho" acaba indicando também ao significado de família (mãe, filhos), o que demonstra a questão da ancestralidade, isto é, "é um principio regulador das práticas e representações do povo-de-santo", (OLIVEIRA, 2006, p. 03), sendo por isso o principal elemento da cosmovisão africana.

A cultura afro-brasileira é interpretada como aquela que os avós faziam suas práticas, costumes e danças, por exemplo, e que ensinaram aos seus filhos, perpassando, até chegar aos seus descentes que hoje cantam os pontos de pretos-velhos nos terreiros. Essa relação de continuidade é o que o conceito da ancestralidade e da cosmovisão africana definidas por Oliveira (2006):

A ancestralidade é como um tecido produzido no tear africano: na trama do tear está o horizonte do espaço; na urdidura do tecido está o tempo. Entrelaçando os fios do tempo e do espaço cria-se o tecido do mundo que articula a trama e a urdidura da existência. (OLIVEIRA, 2006, p. 245)

Há de se destacar, também, a imagem da vovó sentada no banco tosco com rosário na mão é a representação mais frequente quando se fala dos pretos e pretas velhas, como aqueles sempre pacientes, encurvados ou abaixados, voz mansa e doce, com cachimbo na mão, de movimentos calmos e leves. Essa figura é uma das mais representadas quando esses guias são pintados em quadros, por exemplo.

Quando se fala em avô e avó, é um aspecto relevante falar sobre memória, pois a sabedoria, conselhos, experiências de vida, afetividade e cuidados são associações que podemos ter quando fazemos essa relação entre memória e avós. O respeito e a sabedoria dessas pessoas são indiscutíveis, sendo a partir dos avôs e avós que conhecemos nossas próprias histórias e percebemos o quanto nós precisamos ainda aprender.

Então, no momento que escutamos no ponto Vovó Maria Redonda: Filho se suncê/ É só pensar na vovó/ Que ela vem te ajudar, percebemos a proteção, a afetividade e onipresença que os avôs simbolizam. Por meio da memória, podemos lembrar das nossas próprias avós que nos acolhem e cantam, a imagem que a lembrança guarda é desse conforto sempre quando precisamos. 
Há de se considerar, também, a casa branca ao final da estrada, onde a vovó Maria Redonda mora, podemos nos remeter a própria vida encarnada, nem todos os pretos-velhos viveram nesse plano, essa vovó ao contrário, viveu, e quando estava com muitas dores nas pernas e problemas para se locomover, fora construída uma casa afastada e separada da senzala, onde viveu até a sua morte. Quando escuto esse trecho do ponto, a imagem da casa branca, ao longo da estrada, ela sentada no banquinho segurando o rosário, pode nos indicar a vida encarnada da Vovó Maria Redonda. Destaco agora o ponto de Pai Antônio:
Dá licença Pai Antônio
Que eu não vim the visitar
Eu estou muito doente
Vim pra você me curar
Se a doença for feitiço
Pai Antônio vai levar
Se a doença
For pro mal
Pai Antônio vai curar
Coitado de Pai Antônio
Preto Velho curandor
Foi parar na detenção
Por não ter um defensor
Pai Antônio é quimbanda, é curandô
Pai Antônio é quimbanda, é curandô
É pai de mesa, é curandô
É pai de mesa, é curandô
Pai Antônio é quimbanda, é curandô
Pai Antônio é quimbanda, é curando
Disponível em: <http://pisanaumbanda.blogspot.com.br/2010/11/pontos-de-pretos-ve- lhos_18.html>. Acesso em: 10 de janeiro

Nesse ponto, acredito ser importante perceber, especialmente, o motivo de chamar Pai Antônio, quando estamos doentes, "Dá licença Pai Antônio/ Que eu não vim lhe visitar/ Eu estou muito doente/ Vim aqui pra me curar", a pessoa que chama por Pai Antônio não vai para simplesmente lhe visitar, está doente e precisa da ajuda do preto-velho, ou seja, Pai Antônio é "curador" podendo ser inclusive feitiço, mas mesmo assim, ele defende e cura.

Outra situação que deve destaque é a segunda parte do ponto, o qual é descrito que foi parar em uma detenção, por não ter ninguém para o defender, mas Pai Antônio apesar de ser injustiçado é "quimbanda", em outras palavras, aquele que pratica a cura, por isso que Pai Antônio é chamado curador. Assim como todas as falanges de assistência, ele está também a serviço do bem, com o intuito de restabelecer a saúde. Além do mais, a palavra quimbanda tem origem em línguas africanas, nos remetendo a própria questão da ancestralidade negra:

QUIM ou KIM, quer dizer em linguagem africana, médico ou grão-sacerdote dos cultos BANTOS. BANDA quer dizer LUGAR ou CIDADE. Resumindo, chegamos à conclusão de que em nosso idioma, quimbandeiro quer dizer grão-sacerdote dos cultos bantos, vindos de angola, moçambique e benguela.

Disponível em: <http://www.espiritualismo.info/kimbanda.html>. Acesso em: 10 de janeiro.

A questão de sofrer com injustiças e punições como menciona o ponto de Pai Antônio

https://periodicos.unifap.br/index.php/letras

Macapá, v. 8, n. 3, $2^{\circ}$ sem., 2018 
pode ser muito bem relacionada às péssimas condições que o negro no período da escravidão vivia, aqui indico a questão do corpo sendo torturado, punido e desumanizado, apenas pelo fato de ser negro. É inegável que, o corpo para a identidade e resistência negra é fundamental,

Se você quer afirmar sua negritude, o corpo está presente, reafirmando. Se você quer negar, é este mesmo corpo que você tenta subverter e fazer com que se aproxime do corpo branco padrão. Para falar do corpo negro como marca identitária não se pode perder de vista que o corpo negro porta consigo o baú de histórias de Ananase. É um corpo que sempre terá uma tarefa coletiva, fala por si, mas também fala por uma raça e pela ancestralidade. [...] No corpo de cada um de nós, onde quer que estejamos, existem muitas histórias nele gravada, que pode ser tanto uma história de negação, quanto uma história de luta de resistência, o que nos incumbe de uma grande responsabilidade, porque não é só a nossa história individual que estamos construindo. (DEUS, 2011, p. 2)

Aliás, é válido ressaltar, que o corpo mencionado no ponto de Pai Antônio é bastante significativo, pois Zélia Amador de Deus (2011) fala sobre essa importância para a ancestralidade africana. A autora nos mostra que os negros que embarcaram trouxeram parte da África com eles, em "fragmentos de comportamentos restaurados" (DEUS, 2011, p. 61), ou seja, as giras e os pontos cantados são pedaços restaurados da memória africana. A letra dos pontos aqui expostos podem ser interpretadas como a memória do trabalho árduo, a assistência dos Pretos-Velhos, a afetividade, a resistência e força por meio da fé que eles trazem e representam.

No caso do corpo negro a maior tensão encontra-se no aspecto social é o corpo marcado pelo racismo. [...] O corpo tem memória, tem mistérios. Ao mesmo tempo em que desnuda, cobre. Através do corpo o ser pode ser visto julgado. Na cultura ocidental o corpo costuma ser o grande culpado. Ele aparece, atrapalha, dói, adoece, engorda, estica, infla, murcha e envelhece. Trai, treme e trepida. Carrega a alma. Ele é o primeiro que aparece e o último também. É o culpado do pecado. Reveste o bom homem e a boa alma. Acolhe o assassino e o psicopata. Ele age e reage. (DEUS, 2011, p. 7)

No trabalho Arkhé: corpo, simbologia e ancestralidade como canais de ensinamento na educação de Sandra Haydée Petit e Norval Batista Cruz, conseguimos ver a dimensão do corpo e sua importância para a cultura negra no Brasil, pois, mesmo sem ofender ou fazer algo que possa estar preso, o corpo do homem negro gerou e ainda geram castigos, punições e preconceitos. O corpo negro carrega em si o cabelo, a boca, o nariz, a pele, a espiritualidade e a ancestralidade da cultura afro-brasileira e, por isso, a repressão de todos esses elementos e características.

Se por um lado, o corpo sofre coerção, por outro lado, ele acaba sendo símbolo de resistência, força e luta diária, como nos aponta os autores Petit e Cruz (s/d). O que parece acontecer com Pai Antônio, "Foi parar na detenção/ Por não ter um defensor", preso sem justificativa, por ser negro e por carregar consigo essa ancestralidade, fora preso.

Há também no ponto da Vovó Catarina, em sua descrição é apresentada como aquela estrela-guia iluminada, como luz divina, veio de Aruanda, recebendo esse nome de Oxalá,

Ecoou

Um canto vindo de longe ecoou

um lindo dia

Uma luz no céu brilhou 


\section{Sobre a estrela guia}

Iluminada chegou

A Preta-Velha de Aruanda luz divina

Recebeu de Oxalá o nome de Catarina

Disponível em: <http://www.pontosdeumbanda.com.br/pretosvelhos/ponto-de-preto-velho-bahia-e-africa-vem-ca-nos-ajudar.html> . Acesso em: 10 de janeiro de 2017.

Oxalá é o orixá, que no Itã (relatos místicos da tradição Iorubá, funda o universo, pois antes tudo pântano criando o "lugar conhecido como Ifé ('ampla morada') (BARBOSA, 2015, p. 118-119). E os orixás "são elementos da natureza [...] ao cultuar os orixás está se cultuando as forças elementares oriundas da água, da terra, do ar e do fogo. Essa força em desequilíbrio produz uma enorme energia que nos auxilia no dia-a-dia ajudando-nos para que tudo mais favorável." (FAGUNDES, s/d, p. 7).

Por isso, que podemos associar a Vovó Catarina como uma ligação com os Orixás, portanto, com a ancestralidade negra. Oxalá é símbolo de sabedoria, a serenidade, a inocência do branco e o respeito (BARBOSA, 2015, p. 170) dialogando com a benevolência e calmaria dos pretos-velhos, Vovó Catarina, portanto, é luz, estrela e guia de Oxalá. A palavra "aruanda" mencionada no ponto acima indica o espaço onde os Guias permanecem, como morada, até o momento de os guias descem.

Em outro ponto cantado, da Vovó Maria Conga há vocábulos como "congá" e "terreiro" os quais têm o mesmo significado, altar (JÚNIOR, 2015, p.62), é o lugar onde se conectam as energias, a ligação com o espiritual e o retorno a terra, por isso precisamos entrar no congá de pés descalços. Nesse espaço, surge a Vovó Conga para trabalhar:

O risca ponto no terreiro

Tem preta velha no congá

Segura pemba mizi fio

Que vovó Conga vai riscar.

Disponível em: <http://reidospontos.blogspot.com.br/p/pontos-de-preto-velho.html. >. Acesso em: 10 de janeiro.

E por último, finalizo com o canto que acredito ser muito simbólico, pois remete a elementos discutidos no trabalho, a força da ancestralidade e o seu entrelaçamento com o território:
Bahia, Oh África
Vem cá, vem nos ajudar
Força baiana
Força africana
Vem cá, vem nos ajudar.
Disponível em: <http://www.pontosdeumbanda.com.br/pretosvelhos/ponto-de-preto-ve- lho-bahia-e-africa-vem-ca-nos-ajudar.html>. Acesso em: 10 de janeiro.

A ancestralidade é identificada no ponto cantado acima, quando remete aos territórios africano e baiano, indica a continuidade, entre os antepassados e gerações futuras, essa ideia é assentada na ideia de Mãe-terra, como um depositário de elementos-símbolos e terras vividas pelos deuses e ancestrais negros que devem ser restabelecidos. Trazendo a tona à questão do pertencimento, já que tenta de alguma forma, traçar uma linha genealógica, em uma espécie de ligação do próprio passado. 
Para os negros vítimas do escravismo criminoso foi fundamental, diante do esfacelamento dos laços familiares e da desterritorialização forçada, a recriação de uma linhagem para a transmissão e preservação de sua comunidade. Tal linhagem foi providenciada sobretudo pelo terreiro de candomblé, enquanto espaço ritualístico de recomposição e reelaboração dos elos fragmentados pela sociedade que destinava o negro, quer seja ao lugar da subserviência, quer seja ao não lugar (sem direito a terra, e na pós-abolição também excluído da moradia e do emprego pela preferência dada ao emigrante europeu). (CRUZ, 2009, p.25)

Além do mais, o espaço é citado por Ferreira (2003) com a definição de arqueologia essencial, pois fala que mesmo os sujeitos sofrendo alguma tragédia ou desastre, há ainda uma necessidade de retornar a terra, "uma captura intensificada pelo desejo de trazê-lo ao presente como lastro, conforto ou mesmo garantia de vida" (FERREIRA, 2003, p. 31). A forte relação com a terra é quase uma tentativa de um retorno às origens, a um passado que deseja ser presente (África e Bahia, respectivamente), acredito que essa perspectiva da autora retrata o que foi exposto nessa pesquisa, porque está diretamente ligada a importância que os afro-descentes dão a sua terra e a cultura ancestral.

Como contraponto a toda a memória dolorosa e recusada, apresentada em conflito, em consciência, que se estende, desenrola e explode? [...] O sentimento prazeroso que, desde o projeto e decisão desta viagem, o levo a sonhar com ela. $\mathrm{Na}$ viagem em direção ao outro tem grande peso em situações mais gerais e aqui em especial, a preparação, os projetos, a alegria da conquista de um antiespaço, como algo que parecia estar pairando à espera da descoberta que iria fazer. (FERREIRA, 2003, p. 52)

Em outras palavras, o que posso encontrar ao fazer um retorno à Bahia e à África? Assim, as leituras dos pontos cantados podem ser esse diálogo regresso com a ancestralidade e memória de arqueologia essencial, em uma tentativa de reencontrar espaços, histórias, tempos e experiências que compõem as giras de cura dos Pretos e Pretas velhas da Tenda Luz do Oriente.

\section{Oh Gira, deixa a Gira girar: sentindo os ciclos da vida}

O movimento de giro me remete a um constante retorno, pois o seguir de nossas vidas nunca é linear, portanto, estamos sempre buscando nas experiências que vivemos o impulso para seguir. A presença do passado reverbera em nossa existência, como se fossemos moradia de acontecimentos que ainda ecoam na mente, é o que atribuímos como sendo nossa memória.

A memória é elemento chave nas giras, vi que a cada palavra dita era uma emoção vivida, os pontos cantados dos vovôs e vovós tocam a todos pela singela palavra que a mensagem traz, eram desconhecidos para mim, até então, mas ao final desse ciclo, já lembrava alguns, recordava de algumas palavras de outro e cantava vários, passaram pelas diversas vozes do terreiro até chegar à minha memória. A partir do trabalho executado, pude entender algumas questões étnico-raciais no campo religioso, principalmente, a questão da ancestralidade vivida dentro do terreiro de Umbanda, por meio dos gestos, dos falares, dos pontos cantados e riscados, de bater cabeça, dos jongos depois da assistência, vi que tudo era uma reconstrução diária da herança negra.

Os pontos cantados e todas as atitudes feitas durante as giras foram observadas e aos poucos entendidas, as idas para as giras possibilitaram a compreensão não só dos pontos cantados, mas também como uma experiência enriquecedora que permitiu um crescimento 
para a pesquisa e para a pesquisadora. O que foi vivido durante a pesquisa de campo, nos últimos três meses, deram-me várias inquietações, conflitos, dúvidas em relação ao próprio objeto e também pessoais.

O terreiro é, sem dúvida, um lugar de muitas energias, vibrações e força dos guias que nos dão muitas bênçãos e curas, "umbanda é vivência, não esquece de pôr isso no seu trabalho, a umbanda é vivência”, isso quem me disse foi seu Zé Baiano na última gira que fui, contei sobre minhas idas a tenda e as inquietações em falar sobre o terreiro, pois não queria de nenhuma forma desrespeitá-los, e ele então, com a sua sabedoria, me disse tais palavras, ainda me pediu um abraço ao final da nossa conversa, me senti acolhida, em uma espécie de retorno a minha casa e minhas memórias.

Nessa pesquisa estiveram envolvidos não somente as minhas idas a Tenda Luz do Oriente, como várias pessoas que me apoiaram, auxiliaram e ajudaram de maneira muito significativa, pois uma pesquisa de campo demanda não somente tempo, como colaboração de várias pessoas, que sem elas não daria para realizar sozinha, foram a minha família, amigos e a professora orientadora que foi fundamental para esse trilhar.

A memória é vivida, recriada, reincorporada em todas as giras, palavra por palavra reconfigura os cenários, os tempos e as ações dos Pretos-Velhos, ancestrais, era corpo e voz em uma gira reorganizando os ciclos. O estudo sobre essa temática que se abriu a partir desse artigo não se conclui por aqui, o que foi apresentado acaba sendo como um embrião para novos interesses que andam latentes e que indagarei em outro momento oportuno. Por enquanto, vejo o quanto cada ida à tenda e cada palavra escutada dos guias, com muita atenção, fizeram o caminho de volta para casa, para as minhas raízes, mostrando o quão nossas vidas são cíclicas e que não podemos fazer nada contra um deus maior que é o Tempo, narrador e maquinário das nossas próprias vidas. Enfim, adorei as almas ${ }^{18 !}$

\section{REFERÊNCIAS}

BARBOSA, Ademir Júnior. Dicionário de Umbanda. São Paulo: Anúbis, 2015.

BASTIDE, Roger. A poesia afro-brasileira. São Paulo: Martins Fontes, 1943.

BERND, Zilá. Literatura e identidade nacional. Porto Alegre: Universidade Federal do Rio Grande do Sul, 1992.

CUMINO, Alexandre. História da Umbanda: uma religião brasileira. São Paulo: Madras, editora, 2015.

CRUZ, Norval Batista. Consciência corporal e ancestralidade africana: conceitos sociopoéticos produzidos por Pessoas de Santo. 2009. 202f. Dissertação. (Mestrado em Educação) - Universidade Federal do Ceará. Fortaleza-CE, 2009.

CRUZ e PETIT, Norval Batista Cruz e Sandra Haydée Petit. Arkhé: corpo, simbologia e ancestralidade como canais de ensinamento na educação. Revista eletrônica. Fortaleza. s/d.

DEUS, Zélia Amador de Deus. O corpo negro como marca identitária na diáspora africana. Artigo eletrônico. Salvador. V. 11, p. 1-11, 2011.

DEUS, Zélia Amador de Deus. Espaços africanizados no Brasil: algumas referências de resistência, sobrevivências e reinvindicações. Artigo eletrônico. V.3, N.2, p. 59-71, 2012.

18 Adorei as almas: saudação para os Guias chamados de Pretos-Velhos. 
DINIZ, Edson Soares. Um terreiro de Umbanda em Belém do Pará - terreiro do Rei Taculumi. Belém do Pará: 1960.

FERREIRA, Jerusa Pires Ferreira. Armadilhas da memória e outros ensaios. São Paulo: Editora Ateliê Editorial, 2003.

FURUYA, Yoshiaki. Umbandização dos cultos populares na Amazônia: a integração ao Brasil?. ln: Shakai Kagaku Ronshú. Universidade de Kyúshú. Artigo eletrônico. v 31, p. 11-59, 1994.

KLOPPENBURG, Boaventura. A Umbanda no Brasil. Rio de Janeiro - Petrópolis: Editora Vozes Limitada. Estudos, 1961.

OLIVEIRA, Eduardo David de. Filosofia da Ancestralidade: corpo e mito na Filosofia da Educação Brasileira. Curitiba: Editora gráfica popular, 2007.

. Cosmovisão africana no Brasil: elementos para uma filosofia afrodescendente. Curitiba: Editora Gráfica Popular, 2006.

PIMENTEL e FARES. Danieli dos Santos Pimentel e Josebel Akel Fares. Poéticas orais na Ilha de Colares-PA: proposta para uma cartografia da voz e da cultura. Artigo eletrônico. Nau literária: crítica e teoria de literatura. Porto Alegre, v. 9, n. 1, p. 1-20, 2013. PIMENTEL e FARES. Danieli dos Santos Pimentel e Josebel Akel Fares. Cartografias poéticas e outros imaginários em literatura oral. Artigo eletrônico. $2^{\circ}$ Encontro ouvindo coisas: experimentações sob a ótica do imaginário. Universidade Federal de Santa Maria. Novembro, v.2, p.1-9, s/d.

SANTOS, Luís Carlos. Ancestralidade e Liberdade: em torno de uma filosofia africana no Brasil. Revista Sul-Americana de Filosofia e Educação - RESAFE. n. 18, p. 2847, maio-outubro, 2012.

UNIVERSIDADE DO ESTADO DO PARÁ, Centro de Ciências Sociais e Educação. Normas para apresentação de trabalhos. Belém, UEPA, 2008.

VERAS, Hermes de Sousa. O sacerdote e o aprendiz: etnografia, experiência e ritual em um terreiro de Mina Nagô na Amazônia. 2015. 158f. Dissertação (mestrado em antropologia) - Universidade Federal do Pará. Belém-PA, 2015.

ESPIRITUALISMO. Disponível em: <http://www.espiritualismo.info/kimbanda.html.>. Acesso em: 10 de jan. de 2017.

SEMENTEIRA pinta céu Tenda Luz do Oriente. Disponível em: <http://sementeirapintaceutendaluzdooriente.blogspot.com.br/>. Acesso em: 10 de jan. de 2017.

REI dos pontos. Disponível em: <http://reidospontos.blogspot.com.br/p/pontos-depreto-velho.html>. Acesso em: 10 de jan. de 2017.

PONTOS de umbanda. Disponível em: <http://www.pontosdeumbanda.com.br/pretosvelhos/ponto-de-preto-velho-bahia-e-africa-vem-ca-nos-ajudar.html>. Acesso em: 10 de jan. de 2017.

PISA na umbanda. Disponível em:<http://pisanaumbanda.blogspot.com.br/2010/11/ pontos-de-pretos-velhos_18.html>. Acesso em: 10 de janeiro de 2017. 